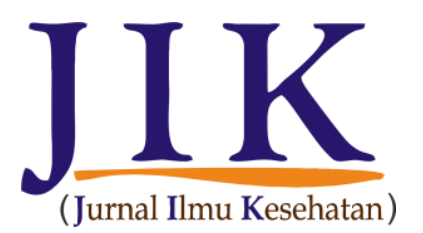

JIK (Jurnal Ilmu Kesehatan)

Online ISSN: 2597-8594

Print ISSN: 2580-930X

Jurnal homepage: https://jik.stikesalifah.ac.id

\title{
Perbedaan Tingkat Pengetahuan dan Sikap Terhadap Penyuluhan Cuci Tangan Pakai Sabun Pada Siswa SD
}

\author{
Meyi Yanti ${ }^{1}$, Alkafi $^{2}$, Bustami $^{3}$ \\ ${ }^{1,2,3}$ Program Studi Kesehatan Masyarakat, STIKes Alifah Padang. \\ Jalan Khatib Sulaiman No.52 B Kelurahan Ulak Karang Selatan, 25134 \\ email: ${ }^{1}$ meyiyanti5@gmail.com, ${ }^{2}$ Alkafi@gmail.com, ${ }^{3}$ bustami1951@gmail.com
}

\begin{abstract}
Abstrak
Menurut studi WHO tahun 2017 menyatakan, kejadian diare menurun 45\% dengan perilaku mencuci tangan pakai sabun, 32\% dengan meningkatkan kasus masyarakat terhadap sanitasi dasar, dan 39\% perilaku pengelolaan air minum yang di rumah tangga, dengan upaya tersebut kejadian diare menurun sebesar 94\%. Penelitian ini bertujuan untuk mengetahui perbedaan rata-rata pengetahuan dan sikap sebelum dan sesudah intervensi tentang cuci tangan pakai sabun dengan metode audiovisual terhadap siswa Kelas III- IV SD. Penelitian ini menggunakan analisis univariat untuk mengetahui rata-rata variabel dan bivariat dengan uji dependent sample T test dengan tingkat kepercayaan 95\%. Desain penelitian ini adalah pretest dan posttest dengan melakukan penyuluhan tentang CTPS dengan metode audiovisual. Penelitian ini dilakukan pada bulan Mei - Juli 2019 dengan populasi penelitian adalah siswa kelas III-VI. Hasil penelitian menunjukkan Rata-rata tingkat pengetahuan siswa sebelum dan sesudah diberikan penyuluhan tentang CTPS dengan metode Audiovisual adalah 10,16 dan 16,31 dengan standar deviasi sebesar 3,60 dan 2,41, Rata-rata sikap siswa sebelum dan sesudah diberikan penyuluhan tentang CTPS dengan metode Audiovisual adalah 38,28 dan 49,84 dengan standar deviasi sebesar 3,50 dan 3,32, terdapat perbedaan yang siginifikan tingkat pengetahuan dan sikap sebelum dan sesudah diberikan penyuluhan tentang CTPS dengan metode Audivisual di SD Muhammadiyah Ketaping Kota Padang tahun 2019.
\end{abstract}

Kata kunci: CTPS, Pengetahuan, Sikap

\section{Differences of Knowledge and Attitude Levels of Soap Washing Display at Elementary Students}

\begin{abstract}
According to the WHO study in 2017 states, diarrhea incidence decreased by $45 \%$ with soap-using handwashing behaviors, $32 \%$ by raising the public case against basic sanitation, and 39\% the behavior of drinking water management in the household, with such efforts Incidence of diarrhea decreased by 94\%. The purpose of this research is to know the average difference in knowledge and attitude before and after the counseling about handwashing soap with audiovisual methods to students of class III-IV Elementary School. This research uses univariate analysis to determine the average of variables and bivariate with the sample dependent test T-test with a confidence level of 95\%. The design of this research is pretests and posttest comparing before and after the counseling about CTPS with audiovisual method. This study conducted in May - July 2019 with the research population, is a class III-VI student. The results showed the average student knowledge level before and after given the counseling about CTPS with Audiovisual methods is 10.16, and 16.31 with standard deviation of 3.60 and 2.41, average attitudes of students before and after Given the counseling about the CTPS with Audiovisual methods is 38.28 and 49.84 with standard deviation of 3.50 and 3.32, there is a significant difference in the level of knowledge and attitude before and after given counseling about CTPS with Audiovisual method at SD Muhammadiyah Ketaping Kota Padang in 2019.
\end{abstract}

Keywords: Hand washing, Knowledge, Attitudes

JIK (Jurnal Ilmu Kesehatan) | Volume 3 No. 2 doi : 10.33757/jik.v3i2.219 


\section{PENDAHULUAN}

Berdasarkan peraturan kementerian kesehatan, Pembangunan kesehatan pada periode 2015-2019 salah satunya adalah Program Indonesia Sehat dengan sasaran meningkatkan derajat kesehatan dan status gizi masyarakat melalui melalui upaya kesehatan dan pemberdayaan masyarakat yang didukung dengan perlindungan finansial dan pemerataan pelayanan kesehatan (Kepmenkes RI, 2015).

Virus rota yang mengakibatkan penyakit Diare sangat cepat menular dan mudah menginfeksi sehingga tidak dapat diabaikan. Center for Disease Control (CDC) and Preventation Amerika Serikat mencatat, ada 10.080 kematian tahun 2007, lebih dari $80 \%$ kematian akibat diare terjadi di Afrika dan Asia Selatan. Di Asia Selatan, India memiliki beban terbesar dari diare. Di India sekitar 0,4 juta anak meninggal setiap tahun karena Diare. Berdasarkan dari hasil penelitian yang dilakukan oleh Sari, menunjukkan bahwa pemberian promosi kesehatan tentang pengetahuan dan sikap CTPS mengalami perubahan yang signifkan (Sari, 2013).

Masa usia anak berbeda antar generasi yaitu dari dari tingkat pra sekola sampai sekolah menengah atas. Permasalah kesehatan anak sangat ditentukan berdasarkan kualitas anak dikemudian hari. Masalah kesehatan tersebut meliputi kesehatan umum, gangguan perkembangan, gangguan perilaku dan gangguan belajar (Pratama, 2013).

Pengetahuan dan sikap Hidup Bersih dan Sehat di Sekolah adalah segala sesuatu yang dipraktikan oleh peserta didik, lingkungan sekolah maupun guru, pencegahan penyakit dapat dilakukan secara mandiri, dan berperan aktif dalam meningkatkan kesehatannya, dan mewujudkan lingkungan sehat. Indikator PHBS di sekolah; Mencuci tangan dengan air mengalir dan menggunakan sabun, Mengkonsumsi makanan sehat dari kantin sekolah, Menggunakan jamban bersih dan sehat, Olahraga teratur, Memberantas sarang nyamuk, Tidak merokok, Membuang sampah pada tempatnya (Kholid, 2012).
Cuci Tangan Pakai Sabun merupakan kebiasaan yang bermanfaat untuk membersihkan tangan dari kotoran dan membunuh kuman penyebab penyakit yang merugikan kesehatan. Mencuci tangan yang baik membutuhkan beberapa peralatan berikut : sabun antiseptik, air bersih, dan handuk atau lap bersih. Untuk hasil yang maksimal disarankan untuk mencuci tangan selama 20-30 detik (Kemenkes RI, 2017).

Media berasal dari kata medius yang berarti tengah, pengantar atau perantara. Media diartikan sebagai segala bentuk dan saluran yang digunakan untuk menyampaikan pesan dan informasi. Media ini dibutuhkan untuk menjadi perantara antara penyuluh dan peserta didik, namun penggunaannya juga tidak boleh seenaknya yang artinya kesesuaian media harus benar-benar diperhatikan yaitu antara materi yang akan disampaikan, karakteristik peserta didik, dan situasi yang ada. Selain media sebagai alat bantu pembelajaran, media juga dipandang sebagai salah satu sumber belajar. Media pembelajaran akan menambah wawasan pengajar dan peserta didik (Notoadmojdo, 2012).

Media pendidikan dibuat dengan menganut pada prinsip bahwa pengetahuan yang ada pada setiap orang diterima atau ditangkap melalui pancaindera. Pengetahuan seseorang dilihat dari pancaindra yang digunakan semakin banyak dan semakin jelas pula pengertian atau pengetahuan yang diperoleh. Pancaindera yang banyak menyalurkan pengetahuan ke otak adalah mata (kurang lebih $75 \%$ sampai $87 \%$ ), sedangkan $13 \%$ sampai $25 \%$, pengetahuan manusia diperoleh dan disalurkan melalui panca indera yang lain. Berbagai jenis media pendidikan yang digunakan bisa meransang Panca indera (Maulana, 2009).

Tujuan penelitian ini adalah untuk mengetahui perbedaan rata-rata pengetahuan dan sikap sebelum dan sesudah intervensi tentang cuci tangan pakai sabun dengan metode audiovisual terhadap siswa Kelas III- IV SD. 


\section{METODE PENELITIAN}

Penelitian ini bersifat pra eksperimen, dikarenakan jenis penelitian uji beda dua mean dependen (one group pretest and posttest) termasuk ke dalam design yang bersifat pra eksperimen, yang dilakukan pada rancangan ini adalah observasi pertama (pretest) yang dilakukan peneliti agar dapat menguji eksperimen yang dilakukan setelah pemberian intervensi (postest). Data dikumpulkan pada bulan Juli 2019. Populasi dalam penelitian ini adalah siswa SD dengan sampel yang diambil secara purposive sampling adalah siswa kelas III dan IV berjumlah 32 siswa. Analisis data dengan analisis univariat dan bivaiat, dimana analisis bivariat menggunakan uji $\mathrm{T}$ berpasangan.

\section{HASIL DAN PEMBAHASAN}

Tabel 1. Rata-rata tingkat pengetahuan dan sikap siswa sebelum dan sesudah dilakukan penyuluhan tentang CTPS dengan metode Audisvisual

\begin{tabular}{lccccc}
\hline $\begin{array}{l}\text { Veriabel } \\
\text { Tingkat Pengetahuan }\end{array}$ & Mean & SD & SE & Pvalue & n \\
$\begin{array}{l}\text { Pretest } \\
\text { Postest }\end{array}$ & 10,16 & 3,60 & 0,637 & 0,000 & 32 \\
& 16,31 & 2,41 & 0,427 & & \\
Sikap & & & & & \\
Pretest & 38,28 & 3,50 & 0,619 & 0,000 & 32 \\
Postest & 49,84 & 3,32 & 0,587 & & \\
\hline
\end{tabular}

Berdasarkan tabel 1 dari 32 responden rata-rata tingkat pengetahuan pre tes dan pos tes masing-masing sebesar 10,16 dan 16,31 dengan standar deviasi sebesar 3,60 dan 2,41. Berdasarkan hasil uji statistik didapatkan nilai $\mathrm{p}$ sebesar 0,0005 dan nilai $p$ tersebut $\leq 0,005$ maka dapat disimpulkan bahwa terdapat perbedaan yang siginifikan antara rata-rata tingkat pengetahuan sebelum dan sesudah dilakukan penyuluhan tentang Cuci Tangan Pakai Sabun dengan metode Audiovisual.

Hasil penelitian yang mendukung penelitian ini dilakukan oleh (Ary Kurniawan, 2019) di SDN 1 Petungsewu Malang, bahwa promosi kesehatan tentang CTPS berpengaruh terhadap tingkat pengetahuan siswa dengan nilai $p$ value 0,000 lebih kecil dari $\alpha \leq 0,05$. Hal ini menunjukan bahwa dengan pemberian penyuluhan dengan metode audivisual dapat meningkatkan pegetahuan siswa tentang cuci tangan pakai sabun. Pengetahuan merupakan pedoman dalam membentuk tindakan seseorang, karena pengetahuan terjadi setelah seseorang melakukan penginderaan terhadap objek tertentu.

Pengetahuan diperlukan sebagai dorongan psikis dalam menumbuhkan sikap dan perilaku setiap hari yang dapat menstimulasi terhadap tindakan seseorang (Kholid, 2012). Pengetahuan dapat diperoleh dari berbagai informasi salah satunya dengan pemberian promosi kesehatan. Promosi kesehatan adalah proses penyampaian informasi untuk meningkatkan kemampuan masyarakat dalam memelihara dan meningkatkan kesehatan untuk mencapai derajat kesehatan baik fisik, mental maupun sosial. Tujuan promosi kesehatan adalah untuk memberikan informasi yang dapat menimbulkan kesadaran masyarakat mengenai peningkatan kualitas kesahatan baik individu maupun masyarakat (Notoadmojdo, 2012).

Menurut asumsi peneliti pengetahuan mengenai CTPS sangat penting dan sangat perlu untuk ditingkatkan khususnya pada siswa sekolah dasar, karena hiegiene perorangan dimulai dari sedini mungkin agar terhindar dari kumankuman penyakit. Dan sehingga siswa memperoleh informasi tentang pencegahan penyakit yang diakibat oleh kuman ditangan dapat dicegah sedini mungkin.

Dan untuk variabel sikap dari 32 responden rata-rata sikap pre tes dan pos tes masing-masing sebesar 38,28 dan 49,84 dengan standar deviasi sebesar 3,50 dan 3,32. 
Berdasarkan hasil uji statistik didapatkan nilai $\mathrm{p}$ sebesar 0,0005 dan nilai $p$ tersebut $\leq 0,005$ maka dapat disimpulkan bahwa terdapat perbedaan yang siginifikan antara rata-rata sikap sebelum dan sesudah dilakukan penyuluhan tentang Cuci Tangan Pakai Sabun dengan metode Audiovisual.

Hasil penelitian yang mendukung penelitian ini dilakukan oleh Heri \& dkk (2015) di SD Negeri 1 Sepauk, bahwa terdapat pengaruh penyuluhan CTPS terhadap sikap siswa dengan nilai $p$ value 0,000 lebih kecil dari $\alpha \leq 0,005$. Hal ini menunjukan bahwa dengan pemberian promosi kesehatan dapat merubah sikap siswa tentang CTPS. Menurut Maulana (2014), menyatakan bahwa sikap seseorang dapat berubah dengan diperolehnya tambahan informasi tentang objek tertentu melalui persuasi serta tekanan dari kelompok sosialnya. Sikap dapat terbentuk dari adanya interaksi sosial yang dialami individu yang tidak hanya berupa kontak sosial dan hubungan antarpribadi sebagai kelompok sosial tetapi juga meliputi hubungan dengan lingkungan fisik maupun lingkungan psikologi sekitarnya.

Menurut asumsi peneliti, terjadinya perubahan sikap siswa sebelum dan sesudah diberikan promosi kesehatan, disebabkan oleh pemberian promosi kesehatan kepada siswa untuk mengetahui cara CTPS dan penyakit yang disebabkan oleh kuman yang ditularkan langsung dari tangan. Sikap siswa sebelum diberikan promosi kesehatan lebih banyak bersikap negatif karena kurangnya informasi yang diterima oleh responden tentang CTPS baik dari pihak sekolah maupun dari petugas kesahatan salah satunya dari Puskesmas.

\section{SIMPULAN}

Berdasarkan hasil yang didapatkan, dapat disimpulkan bahwa: Rata-rata tingkat pengetahuan siswa sebelum dan sesudah diberikan penyuluhan tentang CTPS dengan metode Audiovisual adalah 10,16 dan 16,31 dengan standar deviasi sebesar 3,60 dan 2,41.

Rata-rata sikap siswa sebelum dan sesudah diberikan penyuluhan tentang CTPS dengan metode Audiovisual adalah 38,28 dan 49,84 dengan standar deviasi sebesar 3,50 dan 3,32 .

Terdapat perbedaan yang siginifikan tingkat pengetahuan sebelum dan sesudah diberikan penyuluhan tentang CTPS dengan metode Audivisual di SD Muhammadiyah Ketaping Kota Padang tahun 2019.

Terdapat perbedaan yang siginifikan sikap sebelum dan sesudah diberikan penyuluhan tentang CTPS dengan metode Audivisual di SD Muhammadiyah Ketaping Kota Padang tahun 2019.

\section{UCAPAN TERIMA KASIH}

Pada kesempatan ini penulis mengucapkan terimakasih kepada Yayasan Pendidikan Alifah Nur Ihklas Padang yang telah memberikan bantuan dana dalam penelitian ini dan juga kepada STIKes Alifah Padang yang telah memberikan izin kepada penulis untuk melaksanakan Tridharma Perguruan Tinggi. Serta terimakasih juga kepada Kepala Sekolah SD Muhammadiyah Ketaping Kota Padaang yang telah memfasil itasi dalam penelitian ini.

\section{DAFTAR PUSTAKA}

Ary Kurniawan, dkk. (2019). Pengaruh Promosi Kesehatan terhadap Pengetahuan dan Sikap tentang Perilaku Hidup Bersih dan Sehat Kelas IV dan V SDN 1 Petungsewu. Nursing News, 4(1), 100-111.

Kemenkes RI. (2017). Panduan Penyelenggaraan Hari Cuci Tangan Pakai Sabun Sedunia (HCTPS) Kedua. Jakarta.

Kepmenkes RI. (2015). Rencana Strategis 
Kementerian Kesehatan Tahun 20152019. No. HK.02.02/MENKES/52/2015. Jakarta.

Kholid. (2012). Promosi Kesehatan. Jakarta: Rajawali Pers.

Notoadmojdo. (2012). Promosi Kesehatan dan Perilaku Kesehatan Edisi Revisi. Jakarta: Rineka Cipta.

Pratama, R. K. . (2013). Pengaruh Pendidikan Kesehatan Terhadap Perubahan Pengetahuan, Sikap dan Perilaku Tentang Kebiasaan Berperilaku Hidup Bersih dan Sehat Siswa SDN 1 Mandong. Ilmu Kesehatan, Surakarta. Universitas Muhammadiyah Surakarta.

Sari, F. . (2013). Pengaruh Promosi Kesehatan Tentang PHBS Cuci Tangna Pakai Sabun (CTPS) dengan Pengetahuan dan Sikap CTPS pada IbuIbu di Pengajian 'Aisyiyah Ranting Bangun Tapan Bantul Yogyakarta Tahun 2013. Ilmu Kesehatan, Yogyakarta. Sekolah Tinggi Ilmu Kesehatan 'Aisyiyah Yogyakarta. 